\title{
Overcoming the Length of Waiting Time of Inpatient Drug Service in Pharmaceutical Installation in Hospital $X$
}

\author{
Sindy Sabatina ${ }^{1}$, Tita Hariyanti ${ }^{2}$, Dewi Lelonowati ${ }^{3}$, Sujiono $^{4}$ \\ ${ }^{1}$ Correspondence Author: Sindy Sabatina: sindysabatina@gmail.com \\ ${ }^{1}$ Master on Hospital Management, Faculty of Medicine, Universitas Brawijaya Malang, Indonesia \\ 2Master on Hospital Management, Faculty of Medicine, Universitas Brawijaya Malang, Indonesia \\ 3Master on Hospital Management, Faculty of Medicine, Universitas Brawijaya Malang, Indonesia
}

${ }^{4}$ Hospital X, Indonesia

I N D E X I N G

Keywords:

Pharmacist;

Service Flow;

Standart Operational

Procedure;

Waiting Time;

\begin{abstract}
A B S T R AC T
Inpatient drug service in the pharmaceutical installation in Hospital X has not met the (MSS) Minimal Service Standard. There is delay in delivering the drug by 3\%, while according to the standard, it should be $0 \%$. Objective Case study was conducted by the researcher aiming to know the factors affecting the length of time of inpatient drug service in the pharmaceutical installation and its solution alternative. Method: The research was carried out qualitatively, in which the data was collected through unstructured interview, FGD (Focus Group Discussion) and observation. The participants involved in the research was 30 people. Result are The research data was analyzed using " 5 why" by grouping the $5 \mathrm{M}$ factors obtained consisting of man, method, machine, material and management into 3 main factors as the causes of the long waiting time. The main factors causing the long waiting time were the absence of time target for each service flow established by the management, incomplete SOP (Standard Operational Procedure), the absence of service flow in accordance with the implementation in the field as well as ineffective and inefficient inpatient pharmaceutical installation layout. Furthermore, in order to obtain the solution, NGT (Nominal Group Technique) was employed to do the assessment obtaining 3 solutions including completing the SOP and designing the inpatient drug service flow in pharmaceutical installation, establishing the target time for each service flow by the management, and designing more effective and efficient layout for the pharmaceutical installation.
\end{abstract}

Pelayanan obat di instalasi farmasi rawat jalan di RS X belum memenuhi SPM (Standar Pelayanan Minimal). Terdapat keterlambatan waktu penerimaan obat yang masih mencapai 3\%, sementara standar SPM adalah 0\%. Tujuan Penulis melakukan studi kasus untuk mengetahui faktor-faktor penyebab atau yang mempengaruhi lamanya pelayanan obat di instalasi farmasi rawat jalan dan alternatif solusinya. Metode: Metode yang digunakan dalam penelitian ini adalah kualitatif. Pengumpulan data yang dilakukan dengan wawancara tidak terstruktur, FGD (Focus Group Discussion) dan observasi. Jumlah partisipan yang terlibat sebanyak 30 orang. Hasil Dari hasil analisis menggunakan metode "5 why" dengan mengelompokan menjadi 5M faktor (man, method, machine, material, manajemen) didapatkan 3 faktor utama akar masalah yang menjadi penyebab lamanya waktu tunggu yaitu belum adanya target waktu untuk tiap tahap alur pelayanan yang ditentukan oleh pihak manajemen, belum lengkapnya SPO (Standar Prosedur Operasional) serta belum adanya alur pelayanan sesuai dengan pelaksanaan di lapangan, dan tata ruang /layout instalasi farmasi rawat jalan kurang efektif dan efisien. Selanjutnya dengan menggunakan tehnik NGT (Nominal Group Technique) yang dilakukan penilaian dari alternatif solusi pemecahan faktor akar masalah didapatkan 3 solusi yaitu melengkapi SPO dan membuat alur pelayanan obat di instalasi farmasi rawat jalan, pembuatan target waktu pekerjaan untuk tiap alur pelayanan yang ditentukan oleh pihak manajemen, membuat tata ruang /layout baru untuk instalasi farmasi yang lebih efektif dan efisien. 


\section{INTRODUCTION}

One of the supporting medical services that must exist in hospital is pharmaceutical installation(2012). As a functional implementing unit, it provides all pharmaceutical services in the hospital (Endang, 2018), in the form of product and service for the medical prescription. Medical prescription is the frontline of the pharmaceutical service of a hospital which defines the medical prescription service quality of the pharmaceutical installation in the hospital, thus it must be managed well (Septini, 2012). The pharmaceutical installation service quality includes the service technique, service process, standard operational procedure, and waiting time to get the service. The Decree of Ministry of Health Number 72 of 2016 regarding the hospital service standard stated that pharmaceutical service is direct and responsible service for the patients related to pharmacy supply aiming to achieve a certain result to improve the patients' life quality (2016).

Drug service waiting time is the range of time starting when the patient submitting the prescription until he receives the drug. The ministry of health states that the waiting time for the finished drug must be $\leq 30$ minutes, while for the compounding drug, it must be $\leq 60$ minutes (Depkes, 2008). Pharmaceutical installation often encounters issue in the form of drug service waiting time. Complaint towards the long waiting time for the drug service reached 60\% (Syukraa, 2012). Service waiting time issue frequently happens in service practice. It then causes patients' unsatisfaction. According to the previous research performed by Nurul Fitriah, there was patients' satisfaction decrease on the service carried out by the inpatient pharmaceutical installation in one of the hospitals type $\mathrm{C}$ in Indonesia by $18.3 \%$ in the terms of drug service waiting time (2016). Laeliyah argued that the quality of health service provided by a health service unit can be determined through the patients' waiting time for the service which also reflects how a hospital manage the service component in accordance with the patients' situation and expectation (2018). Waiting time is not only the component of patients' satisfaction, but also the component of quality care service (Clifford Bleustein, MD et al., 2014).

Research on pharmaceutical service becomes important to be done since the pharmaceutical installation affects the hospital significantly due to the drug turnover produced by the pharmaceutical installation can reach 50-60\% of the hospital budget (2019). The customers' satisfaction is one of the keys to keep the patients. If the patients are not satisfied with the pharmaceutical service, then the patient will shift to the other service provider so that the hospital can lose income (Kotler \& Armstrong, 2011). Various factors affect the pharmaceutical service satisfaction, those are the staffs' behavior, drug information provision, drug availability, facility, location, drug service waiting time and the drug price (Megawati, 2015).

An analysis was conducted on the annual report and the profile of Hospital X in 2018, obtaining that the performance achievement regarding the delay of drug service in the Inpatient Pharmaceutical Installation which has not met the MMS (Minimal Service Standard). The delay of the drug service in the inpatient pharmaceutical service reached 3\%, while the standard was $0 \%$. Based on the survey on patients' satisfaction conducted by the hospital in 2018, the pharmaceutical installation obtained poor score (Lapkin, 2018). A previous study conducted by Dewi Lelonowati to know the main problem of the delay by using FGD method assisted by fishbone diagram continued by questioning techniques of " 5 
why". The research then also looked for the prioritized solution by employing NGT method (2015).

\section{RESEARCH METHOD}

This research was done qualitatively in which the data was collected using field observation, interview, hospital data study, literature study and FGD (Focus Group Discussion) with the related installation. Unstructured and structured observation was done using time motion study on the service process in the hospital and inpatient pharmaceutical installation service (Hasanah, 2017). The interviewee in the research was the head of medical service, the head of pharmaceutical installation, the staff of pharmaceutical installation, and the staff from the other unit related to the patients. The number of research participant was 30 people (Jacqueminet, 2017). Fishbone analysis was used in FGD based on 5M factors (man, method, machine, material, management) to know the issue cause, then the main factor of each bone was looked for using " 5 why" method and pursed into 3 main issue causes. Then, 3 solution alternatives were suggested for each cause obtained and ranked in order to get the best solution which would be implemented in the Plan of Action. The prioritized solution of each issue was chosen using NGT (Nominal Group Technique) technique which is a structured brainstorming to assess the solution alternative in order to solve the problem according to the parameter that has been established by the head of medical service, head of pharmaceutical installation, pharmacist, and pharmaceutical technique staff (McMillan et al., 2014).

The purpose of this research is to help Hospital X know the main factors of the issue which cause the delay of drug service waiting time in the pharmaceutical installation and find the solution alternative to overcome the drug service delay which has not met the standard.

\section{RESULT AND DISCUSSION}

The main factor causing the delay issue in drug service of the inpatient pharmaceutical installation was identified through validity process using FGD involving related units. FGD was assisted by fishbone diagram based on $5 \mathrm{M}$ factors (man, method, machine, material, management) and " 5 why" method (Coccia, 2017). The following table presents the problem formulation and searching of the roots of the problem.

Table 1. Problem formulation and searching of the roots of the problem cause using "5Why" method

\begin{tabular}{|c|l|l|}
\hline No & \multicolumn{1}{|c|}{ Factor } & \multicolumn{1}{c|}{ Root of Problem } \\
\hline 1 & Man & Consideration of the ratio of the workers' financial income \\
\hline 2 & Method & $\begin{array}{l}\text { The absence of time target for each service flow established by } \\
\text { the management }\end{array}$ \\
\hline 3 & Machine & $\begin{array}{l}\text { Incomplete SOP and the absence of service flow according to } \\
\text { the implementation in the field }\end{array}$ \\
\hline 5 & Material & No upgrade of the software for the prescription entry \\
\hline 6 & & Regional government's authority \\
\hline 7 & Management & $\begin{array}{l}\text { Ineffective and inefficient room layout } \\
\text { evaluation }\end{array}$ \\
\hline
\end{tabular}

Data source: Focus Group Discussion of the staff of RS X

There were five roots of problems called as $5 \mathrm{M}$ (man, method, machine, material, management), with several roots of problem for each factor found through " 5 why" method. 
It was identified that there were 7 roots of problem pursed into 3 including the absence of time target for each service flow determined by the management, incomplete SOP and the absence of service flow according to the implementation in the field as well as the ineffective and inefficient layout of the pharmaceutical installation. Three solution alternatives were suggested from the three roots of problem which were than ranked to find the best solution to be implemented in the Plan of Action. The following table presents the solution alternative list of each root of problem.

Table 2. Solution Alternative List

\begin{tabular}{|c|c|c|}
\hline No & $\begin{array}{l}\text { Root of Problem } \\
\text { Cause }\end{array}$ & Solution Alternative \\
\hline 1. & $\begin{array}{l}\text { The absence of time } \\
\text { target for each service } \\
\text { flow determined by } \\
\text { the management }\end{array}$ & $\begin{array}{l}\text { 1. Designing working time target for each service flow determined by the } \\
\text { management } \\
\text { 2. Implementing good communication and coordination between the } \\
\text { management and worker } \\
\text { 3. Implementing clear rule regarding reward and punishment system on the } \\
\text { implementation of service flow }\end{array}$ \\
\hline 2. & $\begin{array}{l}\text { Incomplete SOP and } \\
\text { the absence of service } \\
\text { flow according to the } \\
\text { implementation in } \\
\text { the field }\end{array}$ & $\begin{array}{l}\text { 1. Management completes the SOP of the inpatient pharmaceutical } \\
\text { installation } \\
\text { 2. Management designs the drug service flow in the inpatient pharmaceutical } \\
\text { installation known and approved by all staffs } \\
\text { 3. Socialization of the change of SOP of the drug service in the inpatient } \\
\text { pharmaceutical installation }\end{array}$ \\
\hline 3. & $\begin{array}{l}\text { Inefficient } \\
\text { ineffective } \\
\text { layout }\end{array}$ & $\begin{array}{l}\text { 1. Changing the room layout of the pharmaceutical installation to be more } \\
\text { effective and efficient } \\
\text { 2. Approaching and removing obstacles between the steps in service flow } \\
\text { 3. Renovating the pharmaceutical installation according to the accreditation } \\
\text { regulation }\end{array}$ \\
\hline
\end{tabular}

Data source: Focus Group Discussion of the staffs of RS X

The solution alternatives to solve problem was assed using NGT technique based on the parameters that have been determined by the head of medical service, head of pharmaceutical installation, pharmacist, and staff of pharmacy. Score range of 1 to 5 was given to each solution alternative in which 5 was given to the solution considered as the easiest to be implemented, having bigger chance of success, and is an effective solution with relatively low obstacle which continuously decreases. The filtration on the solution selection based on the score result (1-5) mostly selected by the participant was multiplied by the selected solution criteria weight and then added up. The score and weight of each solution alternative was multiplied and the result was then added by to determine the rank. The solution with the highest rank became the best solution. The following table 3 shows the result of the solution alternative weighting criteria.

After choosing the best solution alternative through the FGD activity together with the management and related units, it was then continued by designing action planning which is clearer and more directed with the person in charge of each activities stage implemented in detailed Plan of Action. The action planning based on the time target of the SOP designing implementation delivered to the inpatient pharmaceutical installation is explained in the form of Gantt chart. 
Table 3. Best Solution Alterative

\begin{tabular}{|c|l|c|}
\hline No & \multicolumn{1}{|c|}{ Solution Chosen } & Rank with Weight \\
\hline 1 & $\begin{array}{l}\text { Completing the SOP and designing the drug service flow in the inpatient } \\
\text { pharmaceutical installation }\end{array}$ & I \\
\hline 2 & Making the working time target for each service flow by the management & II \\
\hline 4 & $\begin{array}{l}\text { Designing new room layout for the pharmaceutical installation which is } \\
\text { more effective and efficient }\end{array}$ & $\begin{array}{l}\text { Implementing good communication and coordination between the } \\
\text { management and workers }\end{array}$ \\
\hline 5 & $\begin{array}{l}\text { Socialization of the change of SOP of drug service in inpatient } \\
\text { pharmaceutical installation }\end{array}$ \\
\hline
\end{tabular}

Data source: Focus Group Discussion of staffs of RS X

Patients' satisfaction is one of the most essential index of the health service quality (Mohseni et al., 2014). The service quality can affect the customers' satisfaction where the service quality affects positively on the patients' satisfaction (Razak \& Finnora, 2017). The waiting time of the prescription service is one of the indicators of the hospital service quality and efficiency. The long waiting time is an issue which is frequently complained by the patient (Vinodhini et al., 2018). Patient considers that the long wait of the queue is something that must be paid expensively with valuable time, causing stress and frustration. Patient considers long waiting time causes the hospital to lose patient and reputation in the community. Long waiting time also causes tension among the staff and can disturbs the service pattern (Fitrianda, 2013). Long waiting time significantly affects populous country with low health staff ratio.

Waiting time management is an essential aspect in financial and able to maintain the hospital customer (Kovacevic et al., 2016), thus factors causing the delay of drug distribution in the inpatient pharmaceutical installation and its solution need to be found. The long waiting time of drug service in the inpatient pharmaceutical installation in Hospital X was identified using fishbone diagram based on $5 \mathrm{M}$ factors (man, method, machine, material, management) and "5 why" formulation. The analysis result using fishbone and "5 why" formulation obtained 6 roots of problem factor which were then pursed into 3 in order to obtain the prioritized issue which is the incomplete SOP according to the implementation in the field and the absence of drug service flow causing the long drug service waiting in the inpatient pharmaceutical installation of Hospital X and not in accordance with the Minimal Service Standard. The prescription service time is the range of time since the prescription is received by the pharmacy staff until when the drug is finally received by the patient. Prescription is doctor's written request to the pharmacist so that the drug can be given to the patient (Permana, 2018)

SOP is document related to the procedure cone chronologically to complete work aiming to obtain the most effective working result from the workers. Every company certainly need a guidelines to do their duty and function of each element or unit aiming to ease, clean and regulate the work. Service flow is the process of patients' service order by the pharmaceutical staff (Sailendra, 2015).

The SOP completeness and service flow affects and supports the organization or company operational activities so that it can run well. Incomplete SOP and the absence of service flow can affect the working system of the working unit. SOP must also be regulated in 
order based on the steps or the working implementation where the work is done, how it is done, and who did it. The SOP of the drug service in the inpatient pharmaceutical installation of Hospital X has not been explained in detail regarding which staff does it, the unclear position of the staff who does each working procedure causing the drug service does not run well. As stated in the SOP of the drug prescription service for BPJS and inpatient patient of Hospital X, the procedure number 3 states that the prescription is received by the staff, the validity is examined by the staff, the prescription completeness is examined, and the pharmaceutical supply availability is checked. Each of them lacks of explanation according to the steps of the service flow staff who is responsible for checking the prescription validity, prescription completeness and pharmaceutical supply availability. There were unclear things in the existed SOP in terms of the steps flow staff who is responsible for checking the validity of the prescription, and the one who is responsible for the pharmaceutical supply availability.

There was also no drug service flow in the inpatient pharmaceutical installation in Hospital X which is easy to read and understood by the pharmaceutical staff therefore the drug service process in the pharmaceutical installation has not run well. Thus, the management needs to complete the SOP and design the drug service flow related to the service order and which staff need to have responsibility in each procedure based on their position.

\section{CONCLUSION}

Factors causing the delay of drug service in the inpatient pharmaceutical installation in Hospital $\mathrm{C}$ is the absence of time target for each service flow determined by the management, incomplete SOP and the absence of service flow with the implementation in the field, as well as the ineffective and inefficient room layout. The best solution alternative to overcome those problems is by completing the SOP and socializing to all staffs as well as designing more complete and clearer drug service flow in the inpatient pharmaceutical installation illustrated in the service flowchart approved by all pharmaceutical staffs.

\section{REFERENCE}

Clifford Bleustein, MD, M., David B. Rothschild, B., Andrew Valen, M., Eduardas Valaitis, P., Laura Schweitzer, M., \& and Raleigh Jones, M. (2014). Wait Times, Patient Satisfaction Scores, and the Perception of Care-See more at: Http://www.ajmc.com/journals/issue/2014/2014-vol20-n5/wait-times-patientsatisfaction-scores-and-the-perception-of-care/P-1\#sthash.qOCJOEmg.dpuf. American Journal of Managed Care, 20(May 2014 5), 393-400.

Coccia, M. (2017). The Fishbone diagram to identify, systematize and analyze the source of general puspose technologies ( $\mathrm{p}$. volume 4 issue 4). Journal of Social and Administrative Sciences.

Depkes. (2008). Keputusan Menteri Kesehatan No 129 tentang Standar Pelayanan Minimal Rumah Sakit.

Endang, S. (2018). Waktu Tunggu Pelayanan Resep Rawat Jalan di Instalasi Farmasi Rumah Sakit Universitas Sumatera Utara.

Fitriah, N., Wiyanto, S., Studi, P., Manajemen, M., Sakit, R., Kedokteran, F., \& Brawijaya, U. (2016). Penyebab dan Solusi Lama Waktu Tunggu Pelayanan Obat di Instalasi Farmasi 
Rawat Jalan Rumah Sakit Causes and Solutions for Waiting Time Duration on Drug Services of Hospital Outpatient. 29(3), 245-251.

Fitrianda, M. I. (2013). Digital Digital Repository Repository Universitas Universitas Jember Jember Digital Digital Repository Repository Universitas Universitas Jember.

Hasanah, H. (2017). TEKNIK-TEKNIK OBSERVASI (Sebuah Alternatif Metode Pengumpulan Data Kualitatif Ilmu-ilmu Sosial). At-Taqaddum, 8(1), 21. https://doi.org/10.21580/at.v8i1.1163

Jacqueminet, A. (2017). CSR implementation in MNEs: The role of distance and prioritization of demands. Progress in International Business Research, 12, 363-378. https://doi.org/10.1108/S1745-886220170000012002

Kotler, P., \& Armstrong, G. (2011). Marketing: An Introduction 10th Edition.

Kovacevic, M., Jovicic, M., Djapan, M., \& Zivanovic-Macuzic, I. (2016). Lean thinking in healthcare: Review of implementation results. International Journal for Quality Research, 10(1), 219-230. https://doi.org/10.18421/IJQR10.01-12

Laeliyah, N., \& Subekti, H. (2018). Waktu Tunggu Pelayanan Rawat Jalan dengan Kepuasan Pasien Terhadap Pelayanan di Rawat Jalan RSUD Kabupaten Indramayu. Jurnal Kesehatan Vokasional, 1(2), 102. https://doi.org/10.22146/jkesvo.27576

Lapkin. (2018). Laporan Kinerja RSUD Dr. Soedomo Trenggalek.

Lelonowati, D., Koeswo, M., \& Rochmad, K. (2015). Faktor Penyebab Kurangnya Kinerja Surveilans Infeksi Nosokomial di RSUD Dr. Iskak Tulungagung. Jurnal Kedokteran Brawijaya, 28(2), 186-194. https://doi.org/10.21776/ub.jkb.2015.028.02.13

McMillan, S. S., Kelly, F., Sav, A., Kendall, E., King, M. A., Whitty, J. A., \& Wheeler, A. J. (2014). Using the Nominal Group Technique: How to analyse across multiple groups. Health Services and Outcomes Research Methodology, 14(3), 92-108. https://doi.org/10.1007/s10742-014-0121-1

Megawati. (2015). Hubungan Mutu Pelayanan Farmasi dengan Kepuasan Pasien Rawat Jalan di Rumah Sakit Baptis Batu. Pascasarjana Fakultas Kedokteran Universitas Brawijaya.

Mohseni, M., Sokhanvar, M., Khosravizadeh, O., \& Mousavi Isfahani, H. (2014). Outpatient waiting time in health services and teaching hospitals: A case study in Iran. Global Journal of Health Science, 6(1), 172-180. https://doi.org/10.5539/gjhs.v6n1p172

Permana, A. A. (2018). Evaluasi Waku Tunggu Dan Kepuasan Pada Pasien Rawat Jalan di RSUD Dr. Loekmono Hadi Kudus Periode Februari-April 2018. Fakultas Farmasi, April, 1-12.

Permenkes RI. (2016). Peraturan Menteri Kesehatan Republik Indonesia No. 72 Tahun 2016 tentang Standar Pelayanan Kefarmasian di Rumah Sakit.

Razak, I., \& Finnora, E. (2017). Pengaruh Kualitas Layanan Dan Citra Perusahaan Terhadap Kepuasan Nasabah. Jurnal Manajemen Bisnis Krisnadwipayana, 5(2), 201-216. https://doi.org/10.35137/jmbk.v5i2.113

Sailendra, A. (2015). Langkah-Langkah Praktis Membuat SOP. Cetakan Pertama. Trans Idea Publishing.

Septini, R. (2012). Analisis Waktu Tunggu Pelayanan Resep Pasien Askes Rawat Jalan di Yanmasum Farmasi RSPAD Gatot Soebroto Tahun 2011. Jurnal Universitas Indonesia. 
Syukraa. (2012). Analisis Kebutuhan Tenaga Berdasarkan Beban Kerja dengan Teknik Work Sampling Menggunakan Metode WISN di Unit Farasi Rawat Jalan Krakatau Medika Hospital Cilegon 2012. Pascasarjana Fakultas Kesehatan Masyarakat Universitas Indonesia, Depok. https://doi.org/10.1002/tox.22101

Vinodhini, A., Seethalakshmi, R., \& Sowdamini, T. (2018). Analyzing the role of lean management in health care: A systematic literature review. International Journal of Mechanical Engineering and Technology, 9(7), 303-312.

Wijaya, H. (2019). Analisis Pelaksanaan Standar Pelayanan Minimal (SPM) Rumah Sakit Bidang Farmasi di Instalasi Farmasi Rumah Sakit Anna Medika tahun 2018. Jurnal Manajemen Dan Administrasi Rumah Sakit Indonesia, 3(1), 1-19. 